\title{
Religious circumcision and the Human Rights Act
}

\section{A R Gatrad, A Sheikh, H Jacks}

\section{Implications for state provision}

M edicine today is in a delicate state of balance between the paternalistic and the modern; an increasingly empowered public demands its rights, while the medical profession is frequently seen as taking refuge behind a shield offered by evidence based medicine. When viewed in this context, it is perhaps not surprising that male religious circumcision-the most widely practised surgical operation in the world ${ }^{1}$-invokes considerable controversy and debate within the secularised West.

It is estimated that one third of the global male population is circumcised. ${ }^{2}$ Both Jewish and Islamic law sanction and indeed promote religious circumcision for males. Of concern then is the observation made by many that despite the presence of sizeable faith communities in Britain that adhere to this tradition, state provision of services for religious circumcision remains, at best, patchy. Religious minority communities demand the right to practice their faith, while medical opinion in Britain has historically derided religious circumcision on the grounds that there is at best, no good evidence that the procedure is of benefit, and at worst, that it constitutes a form of genital mutilation. What, if any, are the implications of the recently introduced Human Rights Act with respect to this continuing debate? In this paper, we summarise the legal arguments for and against religious circumcision in the light of this new legislation, exploring the powers and responsibility of the Secretary of State for Health in ensuring fair and equitable health care provision for all British citizens.

\section{RELIGIOUS CIRCUMCISION}

Pertinent to these deliberations is the need for a basic appreciation of monotheistic faiths with respect to male circumcision. The overview presented here is in no way comprehensive, but rather aims to convey something of the significance of this practice to both Jews and Muslims and helps to underpin the legal debate which follows.

\section{Judaism}

The Old Testament describes AbrahamKirkegard's "Knight of Faith"—as enter- ing into a Covenant with the Divine. One of the prerequisites for becoming "a great nation" was that Abraham should "circumcise the flesh of the foreskin". "Every male among you in every generation shall be circumcised on the eighth day ..." (Genesis xvii, 10-13) exhorts the Biblical teaching, thus laying the foundations for circumcision of Jewish male infants. As a result, the bris is typically a time of great celebration with the baby usually given its Hebrew name on the same day.

\section{Christianity}

Jesus Christ was circumcised on the eighth day, in keeping with Jewish tradition; as the first male followers of Christ were Jews, the Church argued that circumcision was compulsory for converts. ${ }^{3}$ Paul, his disciple, however was of the opinion that Jesus had fulfilled the "Old Covenant" and as circumcision would inhibit the appeal of his gospel, he proclaimed that "in Jesus neither circumcision nor uncircumcision counts for anything" (Galatians v, 6) and this practice was therefore unnecessary. ${ }^{3}$

\section{Islam}

Islam is a close sister religion to Judaism and Christianity and shares with them a Middle Eastern origin. It sanctions religious circumcision for males. Prophet Muhammad instructed his followers to circumcise their male infants on the seventh day of life; as with the Jewish community, the child is usually named on the same day amid festivities, and food is distributed to friends, family, and the destitute to mark the occasion. Muhammad's utterances and actionscollectively known as the Sunnahrepresent an accepted basis for the derivation of religious law, and therefore it is not surprising that the overwhelming majority of Muslims respect this teaching and have their male offspring circumcised. Variations in the timing of the procedure do exist, with some communities delaying the procedure; however, all will insist on circumcision prior to attaining majority (age of 10). To leave this operation for a few years could result in the youth becoming noncompliant-because of fear of the procedure-resulting in dilution of
Islamic values. A further advantage of early circumcision is that the child is able to immediately identify with his culture, which gives him a sense of belonging.

Circumcision in Islam forms one of the five prescribed rituals designed to enhance personal hygiene, the others being: shaving pubic hair regularly, moustache trimming, paring of nails, and removing hair from under the armpit. Although some of these practices are not strictly adhered to by the third generation of Muslims in the UK, all Muslim males are circumcised without exception. It has long been the belief of Muslims that an uncircumcised male is unclean and that the foreskin may harbour disease. ${ }^{4}$ Some Muslim jurists have ruled that marriage to an uncircumcised male is void and that such a person cannot be buried in a Muslim cemetery.

\section{RELIGIOUS CIRCUMCISION IN THE UK}

British born Jewish and Muslim males continue to be circumcised; the difficulties in obtaining religious circumcision on the NHS, however, necessitates frequent recourse to the private sector for the performance of this essential rite. Specially trained rabbis, known as mohels, will typically attend to the needs of the Jewish community. In some parts of Britain, because of a dearth of suitably trained Muslim practitioners, the community also turns to mohels for expediency. More typically however, a Muslim general practitioner (GP) or a paediatrician, working in a private capacity, is approached to carry out the procedure, at an average cost of £50-100.

Attempts by the Muslim community to persuade health authorities to provide religious circumcision on the NHS have largely proved unsuccessful, with only a handful of authorities currently offering this service. The question of male circumcision continues to excite considerable debate in secular Western societies, ${ }^{5}$ and although papers continue to be published indicating that the procedure may offer benefit through protecting against conditions such as HIV infection, ${ }^{6}$ it is perhaps reasonable to conclude that the practice is looked on with contempt by many clinicians.

\section{THE HUMAN RIGHTS ACT AND ITS APPLICATION}

Although in most instances the reason for male circumcision is a religious or cultural one, there is a grey area between this and therapeutic indications. Female circumcision, on the other hand, is perceived as offering no possible therapeutic benefit whatsoever, and therefore represents an interesting comparison when considering the implications of the newly introduced legislation. Although 
female circumcision has been illegal in the UK since the Prohibition of Female Circumcision Act was passed in 1985, it has been perceived as an unnecessary piece of legislation, given that the performance of this operation is considered as "unprofessional conduct" by the General Medical Council. In addition, if performed by someone other than a registered medical practitioner, this would be an illegal act under Common Law for it would be tantamount to aggravated assault against the person.

Neither of these constraints however pertain to male circumcision; it would nonetheless be wrong to justify all operations as having a potential therapeutic benefit, regardless of the motivation for the procedure. There has historically been a far greater enthusiasm for this procedure in the United States, although there appears to be a slight decline in this practice recently. This leads to the rather uneasy conclusion that professional organisations (particularly in the United States) and the criminal law sanction, or at least tacitly approve male circumcision for ostensibly non-therapeutic reasons, such as hygiene. Certainly male circumcision is lawful under English Common Law although consent must be given by those with parental responsibility for the child, and in default of unanimity, by the Court.

The Human Rights Act $1998^{8}$ came into force on 2 October 2000. Articles 3 8 , and 9 are relevant:

\section{Article 3: Prohibition of torture}

- "No-one shall be subjected to torture or to inhuman or degrading treatment or punishment".

Article 8: Right to respect for private and family life

- "Everyone has the right to respect for his private family life, his home and his correspondence".

- "There shall be no interference by a Public Authority with the exercise of this right except ... for the protection of health or morals or the protection of the rights or freedoms of others".

\section{Article 9: Freedom of thought, conscience, and religion}

The relevant paragraph is:

- "Everyone has the right to freedom of thought, conscience and religion; this right includes freedom to change his religion or belief and freedom, either alone or in community with others and in public or private, to manifest his religion or belief, in worship, teaching, practice and observance".

The potential application of Article 3 is obvious, given that circumcision has some pain attached to it (which may be as a result of no local anaesthesia or inadequate anaesthesia) and perhaps more importantly, has almost certainly not been sought or requested by the child, as inevitably of course, the child is an infant. The relevance of Article 8 is that it preserves the right to a private life. In simple terms, for someone to come along unbidden (by the child) and carry out a procedure which causes pain and is not of any immediate obvious benefit, would potentially infringe that right. Conversely the protection within that Article of family life, is clearly pertinent to the child being accepted or rejected within a particular religious or ethnic community. Similar considerations apply in relation to Article 9-it may well be a prerequisite of membership of a particular community (such as the Muslim or Jewish community), that a circumcision has been carried out on the child.

When considering whether there is a breach of a relevant human right, one has to look at the body of the Human Rights Act, and in particular Sections 6 and 7. Section 6 states that it is unlawful for a Public Authority to act in a way that is incompatible with a Convention right. Who is the Public Authority? This will usually be a GP carrying out a publicly or privately funded action. Section 7 states that a person who claims that a Public Authority has acted in a way which is made unlawful by section 6 may "bring proceedings ... but only if he is a victim of the unlawful act". Note the word "victim", which is now enshrined in the statute. Who is the victim? Most obviously, potentially, the child. Who in reality would be bringing any action on behalf of the child? Most obviously the parents. Once the child becomes of age he could arrange for himself to be represented and an action brought other than via his parents. Once he achieves majority, which under English law is 18 years, he can bring an action in his own right as regards anything which occurred during his childhood. The other potential victims are the parents. If their child is rejected by the community because of an omission to carry out the circumcision, the family will naturally be disadvantaged and possibly ostracised.

On what basis might any action be brought? We have already seen the potential application of Articles 3, 8, and 9. So, what might be the defence available to the practitioner, the parent, or against whoever the action was brought? The confirmation of the intrinsic legality of ritual male circumcisions for children came from the courts in the case of Re J, ${ }^{9}$ which explored the issue of male circumcision in May 1999, and on appeal in November of that year the decision of the trial judge in favour of circumcision was upheld..$^{10}$ It is also however clear from this case that where both parents have parental responsibility, the consent from them both is necessary, in default of which consent would need to be given by the Court. The Court is prepared to give its consent in those cases where it is satisfied that this is in the child's interest, for example, being accepted in the community given that Section 1 of the Children Act $1989^{11}$ reminds us that the child's welfare shall be the Court's paramount consideration; this obviously includes the fact that the procedure is carried out without risk and pain.

Case Laws such as the ones cited above therefore seem to indicate that the courts are supposed to operate a high "threshold" test when deciding whether Article 3 has been breached. They will decide, it seems, that this threshold is not crossed in the case of a religiously/ culturally carried out male circumcision. Article 3 is therefore in reality unlikely to be applicable in cases of ritual male circumcision.

What is the likelihood that any Article 8 rights are breached? A child may subsequently reject his own membership of his ethnic or religious community. Any wrong committed must, it seems, relate to the time when the act occurred. Given not only the norms of certain communities but the necessity of this procedure for acceptance of the individual therein, and the undoubted knock on effect on their family, it could be quite cogently argued, one would suspect, that Article 8, and indeed Article 9 rights were breached if the parents deliberately failed to present their child for the procedure at or about the appropriate time.

\section{THE QUESTION OF STATE FUNDING}

To examine this we must look at the 1977 National Health Service Act. ${ }^{12}$ Section 1 states:

It is the Secretary of State's duty to continue the promotion in England and Wales of a comprehensive health service designed to secure improvement:

- in the physical and mental health of the people of England and Wales

- in the prevention, diagnosis and treatment of illness, and for that purpose to provide or secure the effective provision of services in accordance with this Act.

Section 3 states:

It is the Secretary of State's duty to provide throughout England and Wales, to such extent as he considers necessary to meet all reasonable requirements ...

- Such facilities for the prevention of illness, the care of persons suffering from illness and the after-care of persons who have suffered from illness as he considers are appropriate as part of the health service. 
- Such other services as are required for the diagnosis and treatment of illness...

It is obvious that the Secretary of State's powers to provide a health service extend only as far as a therapeutic provision. There is, as has already been observed in some cases, a possibly ill defined area between therapeutic and non-therapeutic reason for the procedure. However, most circumcisions will inevitably be non-therapeutic and hence not within the statutory provision. One has little doubt that there are instances where a Muslim GP will carry out the procedure, without a fee, but were the matter really put to the test and there was clearly no clinical indication for the procedure, then it could not strictly be said to be a case for a free service at the point of delivery. There would therefore appear to be a need to change statute before a non-therapeutic purpose could be the subject of free provision within the NHS; for the time being, current arrangements, inevitably attracting a fee, will have to continue.

\section{CONCLUSION}

Some communities regard body piercing, particularly where it involves areas such as the tongue and genitals, as a form of mutilation of the body. A similar view is taken with respect to tattooing by Muslims, ${ }^{13}$ while other communities may consider ritual circumcision in a similar light. Although medical opinion is currently on the whole against circumcision, as discussed, it is a very important religious symbol for both Muslims and Jews and is here to stay. Any legislation against it in boys will be strongly challenged by both communities. Worse could happen if it is made illegal as suggested by some commentators, ${ }^{5}$ for it would almost certainly be driven underground as has happened with female circumcision. ${ }^{14}$ Some health districts, such as Walsall and Sandwell in the West Midlands, provide this service on the NHS to ensure that the procedure is carried out safely by a surgeon under full local anaesthetic support. Although these procedures in the NHS can cost up to $£ 500$ per "day case", ${ }^{15}$ the question of pain is addressed and the commonest complications of bleeding and infection are minimised.

\section{ACKNOWLEDGEMENTS}

AS is funded by the NHS R\&D National Primary Care Award Scheme.

Arch Dis Child 2002;86:76-78

\section{Authors' affiliations}

A R Gatrad H Jacks, Manor Hospital, Moat Road, Walsall WS2 9PS, UK

A Sheikh, Department of Primary Care and General Practice, Imperial College School of Medicine, London, UK

H Jacks, Mills \& Reeve, 54 Hagley Road, Edgbaston, Birmingham B16 8PE, UK
Correspondence to: Dr A R Gatrad; steadmana@wht.walsallh-tr.wmids.nhs.uk

\section{REFERENCES}

1 Maxwell M. Male circumcisions. Liverpool Public Health Observatory. Issues series 8 April 1996:3.

2 Williams N, Kapila L. Complications of circumcisions. Br J Surg 1993;80:1231-4.

3 Gollaher DL. Circumcision: a history of the world's most controversial surgery. New York: Basic Books, 2000:31.

4 Gollaher DL. Circumcision: a history of the world's most controversial surgery. New York Basic Books, 2000:46.

5 Abboud P, Quereux C, Mansour G, et al. Stronger campaign to end female genital mutilation. BM 2000;320:1153.

6 Szabo R, Short RV. How does male circumcision protect against HIV infection. BM 2000;320: 1592-4.

7 Gollaher DL. Circumcision: a history of the world's most controversial surgery. New York: Basic Books, 2000:126-7.

8 Human Rights Act 1998.www.hmso.gov.uk/ acts/acts 1998/19980042.htm (accessed July 2001)

9 Wall J. Re J-Muslim upbringing and circumcision. Specific Issue Orders. Family Division. Jordan Publishing, May 1999.

10 Butler-Sloss E, Schiemann P, Thorpe LJ. Muslim upbringing and circumcision. Court of Appeal. Jordan Publishing, November 1999

11 Children Act 1989. London: HMSO, 1989.

12 National Health Service Act 1977. www.hmso.gov.uk/si/si1993/ Uksi_19930887_en_1.htm (accessed July 2001).

13 Qadarawi Yusuf. The lawful and the prohibited in Islam. Indianapolis: American Trust Publication, 1985:88.

14 Minority Rights Group. Female circumcision, excision and infibulation: the facts and proposals for change. Minority Rights Group Report No. 47. London, 1983 (revised).

15 Rickwood AMK, Kenny SE, Donnell SC. Towards evidence based circumcision in English boys: survey of trends in practice. BM 